\title{
Common ware production at Thamusida: dating and characterisation of Roman and Islamic pottery
}

\author{
E. Gliozzo • D. D’Aco • I. Memmi Turbanti - A. Galli • \\ M. Martini • E. Sibilia
}

Received: 27 November 2008 / Accepted: 26 February 2009/Published online: 11 March 2009

(C) Springer-Verlag 2009

\begin{abstract}
Twenty-one samples of likely Roman, likely Islamic and unknown common ware from the archaeological site of Thamusida (Rabat, Morocco) were analysed in order to anchor selected types of pottery to a limited time span and, possibly, to a production area and technology. Analytical techniques were thermoluminescence, optical microscopy, scanning electron microscopy and X-ray fluorescence. The results arising from this research are definitely useful for the study of the site of Thamusida as well as for all researchers involved in archaeological and archaeometrical research in Morocco. Chronologies proposed on a typological base have been denied twice: a likely Islamic cup dates back to the second century A.D.; vice versa, a stewpot, framed into the Roman period, resulted to be an eighth century A.D. production. Moreover, the identification of an eighteenth century ceramic produc-
\end{abstract}

E. Gliozzo $(\bowtie) \cdot$ I. Memmi Turbanti

Department of Earth Sciences, University of Siena,

via Laterina 8 ,

53100 Siena, Italy

e-mail: gliozzo@unisi.it

D. D'Aco

Department of Archaeology and History of Arts,

University of Siena,

via Roma 52,

53100 Siena, Italy

A. Galli

CNR-INFM and Department of Materials Sciences,

University of Milano Bicocca,

via R. Cozzi 53,

20125 Milan, Italy

M. Martini $\cdot$ E. Sibilia

Department of Materials Sciences, University of Milano Bicocca, via R. Cozzi 53,

20125 Milan, Italy tion is of outstanding importance, as it characterises a completely unknown production. Regarding the production area, four samples of both Roman and Islamic periods have been recognised as local productions of Thamusida.

Keywords Roman tableware - Islamic tableware - Ceramic . Thamusida (Morocco)

\section{Archaeological background and issues}

In the frame of a comprehensive study of archaeological findings from Thamusida (Rabat, Morocco), common ware of both Roman and Islamic periods deserves a special attention. The archaeological investigations brought to light both pottery and production plants, offering a privileged situation for studying ceramic production and imports (Camporeale 2008; Cerri 2008).

On the other hand, the study of common ware has been often neglected, yet favouring well-known and informative ceramic categories such as Roman terra sigillata or Islamic glazed pottery. Archaeological studies on excavations performed in Morocco examined common ware from defined stratigraphical context only occasionally. Very few typological studies stand for comparison, making hard to indicate a precise chronological framework for this ceramic production or even to distinguish Roman common ware from Islamic one.

References are currently available for findings from the necropolis of Sala (Rabat, Morocco), for the archaeological sites Thamusida (Rabat, Morocco), Lixus (Larache, Morocco), Qsar es-Seghir and al-Basra and for the territories of Qsar es-Seghir, al-Basra, Badis, Madinat En-Nakur, Jebila and Moulay Bou Selham (Fig. 1).

Ceramic materials from the Roman tombs at Sala were studied by J. Boube (1999); however, a typology is lacking 
Fig. 1 Geographical map of northern Morocco where archaeological sites cited in text have been indicated

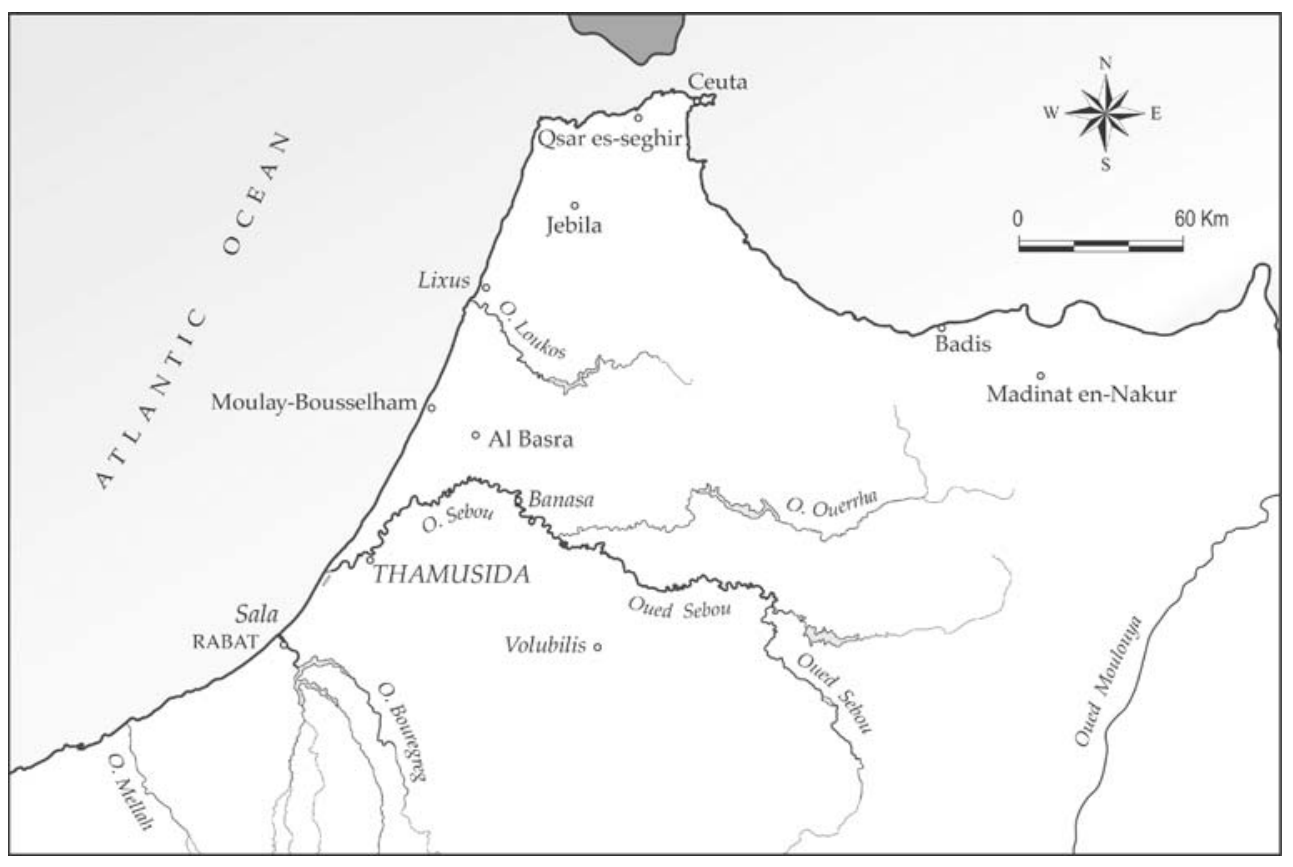

and most of objects are generically indicated as cinerary urns only. The systematic study performed on common pottery from the archaeological investigations of Thamusida (D'Aco 2005) offers a vast and articulated collection of vase morphologies and types with a known chronology. The investigations conducted on the archaeological site of Lixus were mainly focused on Phoenician, Mauro and Roman periods; nevertheless, a typological study of Islamic pottery, especially of Almohad period (twelfth-thirteenth century A.D.) was performed, even though leaving a part the most part of the noncoated productions (Aranegui Gascó 2001, 2005). The publication of the archaeological excavation of Qsar es-Seghir (Redman et al. 1977-1978, 1979-1980) included a study on medieval pottery (Redman 1979-1980) where numerous Islamic and Portuguese decorated and glazed productions were described. Redman (1983-1984) further provided some plates showing numerous types of pottery (including tableware and cooking ware) found during the archaeological excavations and landscape examination of the Islamic sites of Qsar esSeghir, al-Basra, Badis, Madinat En-Nakur, Jebila and Moulay Bou Selham. Lastly, the ceramic materials from al-Basra, the chief town of Morocco under the Idrisid dynasty (eight-tenth century A.D.), were studied by Benco (1987, 2002).

Hence, the state of the archaeological research on common ware from Morocco is in the very early stage, rarely providing information on the most common and diffused class of pottery of both Roman and Islamic world. Furthermore, it is worth considering that political and economic relationships between the above listed sites and Thamusida are only partially known, for Roman age almost exclusively.

In the context of archaeometric research, chemical and mineralogical-petrographical reference groups for local
Moroccan productions are limited to the archaeological sites of Ceuta (Roman stamped bricks; Bernal Casasola 1994) and Thamusida (Roman bricks and amphoras, Islamic bricks; Gliozzo and Camporeale 2009; Gliozzo and Cerri 2009). Chronological measurements have never been performed for the ceramic class under investigation.

By the way, the chronological limits stated of Islamic period in Morocco must be preliminary clarified. At Thamusida, the beginning of the post-Roman age could correspond to the north transfer of the limes, which provoked the abandon of the camp in the last quarter of the third century A.D. (Sigman 1977; Decret and Fantar 1981; Villaverde Vega 2001). In the same period, the Vandals arrived in Morocco from the Iberian peninsula (429 A.D.), but they were defeated by Belisarius in 533 A.D., leading to the annexation of Morocco to the Byzantine Empire. However, based on chronology proposed by Lugan (2000), the Islamic age starts in 683 A.D. when Uqba ibn Nafi conquered the north African coastal plain.

In light of these preliminary remarks, the research is aimed at providing an insight on Roman and Islamic common ware in order to anchor selected types of pottery to a limited time span and, possibly, to a production area and technology. Chronological issues are thus strictly linked to provenance and technological issues for a complete characterisation of the whole sample set.

\section{Materials and methods}

Considering the stated objectives, a total of 21 samples were selected based on proposed chronology and typology 
(Table 1 and Fig. 2). Three sample sets were enucleated: likely Roman, likely Islamic, unknown. The latter group includes vessels that cannot be considered of Roman age but available references do not allow comparison with Islamic productions. Within each group, those vessel types more frequently attested in the territory of Thamusida were selected.

Six samples are likely of Roman age and include two bottles, one jug, two stewpots and one jar. Morphologically, they can all be compared to objects found in the necropolis of Sala (Boube 1999). The two selected bottles, D2074 and D2077, resemble the morphology of the olpai found in numerous tombs (Boube 1999, p. 117, Fig. U) and that of the lekythos found in tomb no. 3 (Boube 1999, p. 117, Fig. U and p. 213), respectively. The former were dated to the Flavian age; the latter between the Claudian and Flavian dynasties. The jug D2076 can be compared to the urn found in tomb no. 186, dated between the age of Nero and that of Vespasian (Boube 1999, p. 46, Fig. E ${ }^{3}$, S. 186 and p. 384-385). Among stewpots, D2075 and D2078 are for cooking, whilst the jar D2079 is for storage. D2075 shows a flared rim, similar to that of urn found in tomb no. 310 and dated back to the mid second century A.D. (Boube 1999, p. 47, Fig. E ${ }^{4}$, S. 310 and p. 486). D2078 shows a very popular shape that derived from Hellenistic tradition and was widely diffused in Roman age in all Mediterranean world. Lastly, D2079 partially resembles the shape of the urn found in tomb no. 105, dated back to the Claudian/Vespasian age (Boube 1999, p. 46, Fig. E $E^{3}$, S. 105 and p. 303).
Five samples are likely of Islamic age and include one cup, three jugs and one basin. Typological comparisons with pottery found in archaeological sites of Islamic age are never decisive. The shape of the rim of cup D2067 is similar to that of a cup found at Badis (Redman 1983-1984, p. 338, Fig. 26h). The jugs D2069, D2071 and D2072 can be all compared to different types of "storage jars" found at the site of al-Basra; in particular, D2069 is similar to shape no. 43, D2071 and D2072 to shape no. 41 (Benco 2002, p. 336, Fig. 11g-h and p. 336, Fig. 11a-c). Proposed chronology for these fragments ranges from the sixth to the ninth century A.D. for the former, between the tenth and eleventh century A.D. for the latter (Benco 2002, p. 307 and pp. 320-323). Lastly, the basin D2073 find a reasonable comparison with a basin from the archaeological site of Badis (Redman 1983-1984, p. 338, Fig. 26).

Ten samples are of unknown chronology and include three basins, four cups, two pans and one jug. For these fragments, any attempt of typological comparison fails. Selection was made based on different morphologies (cup, basin, etc.) and, within each type of morphology, types. Considering the conservation state of the examined collection, the shape of the rim was used as a principal selection criterion: brimmed in D2081 and D2085, retracted brim in D2086 and D2087, moulded in D2082 and D2089, indistinct in D2083 and D2084, thickened in D2088, flanged in D2090.
Table 1 Sample list and description

\begin{tabular}{|c|c|c|c|c|c|c|c|}
\hline & Sample & Shape & Type & Proposed chronology & $\mathrm{TL}$ & $\mathrm{XRF}$ & $\mathrm{OM} / \mathrm{SEM}$ \\
\hline \multirow[t]{6}{*}{ Likely Roman } & D2074 & Bottle & 63 & Second half 1 st cen. A.D. & $\mathrm{X}$ & $\mathrm{X}$ & $\mathrm{X}$ \\
\hline & D2075 & Stewpot & 156 & Mid 2nd cen. A.D. & - & $\mathrm{X}$ & \\
\hline & D2076 & Jug & 46 & Second half 1 st cen. A.D. & $\mathrm{X}$ & $\mathrm{X}$ & $\mathrm{X}$ \\
\hline & D2077 & Bottle & 60 & Second half 1 st cen. A.D. & $\mathrm{X}$ & $\mathrm{X}$ & $\mathrm{X}$ \\
\hline & D2078 & Stewpot & 148 & Roman age & $\mathrm{X}$ & $\mathrm{X}$ & $\mathrm{X}$ \\
\hline & D2079 & Jar & 114 & Second half 1 st cen. A.D. & - & $\mathrm{X}$ & \\
\hline \multirow[t]{5}{*}{ Likely Islamic } & D2067 & Cup & 84 & Islamic & $\mathrm{X}$ & $\mathrm{X}$ & $\mathrm{X}$ \\
\hline & D2069 & Jug & 38 & 6th-9th cen. A.D. & $\mathrm{X}$ & $\mathrm{X}$ & $\mathrm{X}$ \\
\hline & D2071 & Jug & 41 & 10th-11th cen. A.D. & $\mathrm{X}$ & $\mathrm{X}$ & $\mathrm{X}$ \\
\hline & D2072 & Jug & 52 & 10th-11th cen. A.D. & $\mathrm{X}$ & - & $\mathrm{X}$ \\
\hline & D2073 & Basin & 6 & Islamic & - & $\mathrm{X}$ & \\
\hline \multirow[t]{10}{*}{ Unknown } & D2081 & Basin & 31 & - & - & $\mathrm{X}$ & \\
\hline & D2082 & Basin & 30 & - & - & $\mathrm{X}$ & \\
\hline & D2083 & Cup & 80 & - & $\mathrm{X}$ & - & $X$ \\
\hline & D2084 & Basin & 17 & - & $\mathrm{X}$ & $\mathrm{X}$ & $\mathrm{X}$ \\
\hline & D2085 & Cup & 77 & - & $\mathrm{X}$ & $\mathrm{X}$ & $\mathrm{X}$ \\
\hline & D2086 & Cup & 129 & - & $\mathrm{X}$ & $\mathrm{X}$ & \\
\hline & D2087 & Pan & 135 & - & - & $\mathrm{X}$ & $X$ \\
\hline & D2088 & Cup & 81 & - & $\mathrm{X}$ & $\mathrm{X}$ & \\
\hline & D2089 & Jug & 49 & - & - & $\mathrm{X}$ & \\
\hline & D2090 & Pan & 138 & - & $\mathrm{X}$ & $\mathrm{X}$ & $\mathrm{X}$ \\
\hline
\end{tabular}






Fig. 2 Samples and typology. Basins: 1 Type 6, D2073; 2 Type 17, D2084; 3 Type 30, D2082; 4 Type 31, D2081. Jugs; 5 Type 38, D2069; 6 Type 41, D2071; 7 Type 46, D2076; 8 Type 49, D2089; 9 Type 52, D2072. Bottles: 10 Type 60, D2077; 11 Type 63, D2074.

\section{Experimental}

Investigations were performed by means of different analytical techniques: thermoluminescence (TL) dating for absolute chronology, optical microscopy (OM), scanning electron microscopy (SEM-EDS) and X-ray fluorescence (XRF) for chemical and mineralogical-petrographical characterisation.
Cups: 12 Type 77, D2085; 13 Type 80, D2083; 14 Type 81, D2088; 15 Type 84, D2067; 16 Type 129, D2086. Jar: 17 Type 114, D2079. Pan: 18 Type 135, D2087; 19 Type 138, D2090. Stewpots: 20 Type 148, D2078; 21 Type 156, D2075

The method of dating by thermoluminescence is, in principle, quite simple (Aitken 1985), being expressed by the following equation:

Age $($ years $)=$ Paleodose $(\mathrm{Gy}) /$ annual dose $($ Gy per year $)$

where the paleodose is the total dose absorbed by the pottery since its last heating in Antiquity, whilst the annual 
dose is the sum of the internal and external contributions from alpha and beta radiation and from gamma and cosmic radiation, principally due to the presence of uranium-238, thorium-232 and potassium- 40 in the pottery and its surrounding environment. In the pottery, the accumulated dose is recorded by quartz, feldspars and other TL-emitting minerals.

TL measurements were performed using an oven with controlled heating system; the samples were heated in an ultra-pure $\mathrm{N}_{2}$ atmosphere (heating rate $15^{\circ} \mathrm{C} / \mathrm{s}$ ) and the $\mathrm{TL}$ intensity was detected using an EMI 9635QB photomultiplier tube coupled to Corning BG12 blue filters. Beta irradiations were carried out using a $1,400-\mathrm{MBq}{ }^{90} \mathrm{Sr}-{ }^{90} \mathrm{Y}$ beta source $\left(1.20 \mathrm{~Gy} \mathrm{~min}^{-1}\right)$ and alpha irradiations with a $37-\mathrm{MBq}{ }^{241} \mathrm{Am}$ source $\left(14.8\right.$ Gy $\left.\mathrm{min}^{-1}\right)$. The sample preparation and the evaluation of the absorbed dose with a multi-aliquot additive procedure were made following the standard fine-grain technique $(2-8 \mu \mathrm{m}$; Zimmermann 1971). For the pre-dose procedure, a modified protocol was adopted (Galli et al. 2006). Annual dose rates were obtained by total alpha counting with $\mathrm{ZnS}$ scintillator discs and flame photometry performed on the ceramic samples as well as on excavation soils and local clays. To account for the cosmic radiation dose, which could not be directly measured, a contribution of $150 \mu \mathrm{Gy} / \mathrm{year}$ was added (Aitken 1985). In calculating the dose rates, water contents corresponding to the $70 \pm 20 \%$ of water saturation were used.

For SEM investigations, a SEM Philips XL30 equipped with an energy-dispersive spectrometer (EDS) Philips
EDAX DX4 was used. A variety of natural and synthetic materials were used as primary and quality control standards. Operating conditions were as follows: accelerating voltage $20 \mathrm{kV}$, beam current $\sim 30-40 \mathrm{~mA}$, work distance $10-15 \mathrm{~mm}$. Quantitative analyses with the theoretical inner pattern were obtained using the ZAF method of correction.

For X-ray fluorescence, samples were mechanically crushed in a planetary mill and manually ground into a powder in an agate mortar. Quantitative analyses were performed on powder discs obtained by pressing $0.5 \mathrm{~g}$ of sample on a support of boric acid. The XRF apparatus was a Philips MagiX-Pro. Background and mass absorption intensities were calculated using calibrations based on 24 international geological reference materials. Loss on ignition was determined by thermogravimetric way, heating samples - previously dried to $110^{\circ} \mathrm{C}$ for $2 \mathrm{~h}$ - to $1050^{\circ} \mathrm{C}$ for about $1 \mathrm{~h}$.

Small dimensions and lightweight of samples did not allow performing all analytical techniques for each sample (Table 1).

\section{Results}

Thermoluminescence dating

The results of radioactivity measurements together with the corresponding dose rates are reported in Table 2. Table 3

Table 2 Results of radioactivity measurements

\begin{tabular}{|c|c|c|c|c|c|c|c|c|c|c|}
\hline Sample & $\begin{array}{l}\text { Saturation water } \\
(\% ; \pm 5 \%)\end{array}$ & $\begin{array}{l}\mathrm{K}_{2} \mathrm{O} \\
(\% ; \pm 3 \%)\end{array}$ & a value & $\begin{array}{l}\mathrm{U}^{238} \\
(\mathrm{ppm} ; \pm 5 \%)\end{array}$ & $\begin{array}{l}\mathrm{Th}^{232} \\
(\mathrm{ppm} ; \pm 5 \%)\end{array}$ & $\begin{array}{l}\text { Dose Rate } \\
(\mu \text { Gy/year })\end{array}$ & $\begin{array}{l}\text { Dose rate } \\
\alpha(\%)\end{array}$ & $\begin{array}{l}\text { Dose Rate } \\
\beta(\%)\end{array}$ & $\begin{array}{l}\text { Dose rate } \\
\gamma(\%)\end{array}$ & $\begin{array}{l}\text { Equivalent } \\
\text { dose (Gy) }\end{array}$ \\
\hline D2066 & 24.6 & 2.5 & 0.200 & 3.10 & 9.80 & $5.16 \pm 0.27$ & 47 & 38 & 14 & $2.40 \pm 0.24$ \\
\hline D2067 & 21.2 & 0.7 & 0.203 & 2.74 & 8.67 & $3.76 \pm 0.23$ & 58 & 24 & 18 & $6.87 \pm 0.44$ \\
\hline D2069 & 21.9 & 2.8 & 0.182 & 2.99 & 9.47 & $5.14 \pm 0.25$ & 43 & 43 & 14 & $6.35 \pm 0.48$ \\
\hline D2071 & 19.4 & 1.6 & 0.215 & 2.13 & 6.74 & $3.98 \pm 0.19$ & 47 & 35 & 18 & $3.96 \pm 0.21$ \\
\hline D2072 & 22.6 & 1.7 & 0.205 & 2.74 & 8.67 & $4.48 \pm 0.24$ & 50 & 34 & 16 & $4.52 \pm 0.28$ \\
\hline D2074 & 25.9 & 1.7 & 0.215 & 1.98 & 6.26 & $3.64 \pm 0.19$ & 45 & 36 & 19 & $7.31 \pm 0.51$ \\
\hline D2076 & 16.4 & 1.9 & 0.159 & 2.54 & 8.03 & $4.19 \pm 0.19$ & 42 & 41 & 17 & $8.18 \pm 0.55$ \\
\hline D2077 & 11.4 & 2.2 & 0.130 & 2.94 & 9.31 & $4.47 \pm 0.20$ & 39 & 45 & 16 & $8.43 \pm 0.49$ \\
\hline D2078 & 13.9 & 1.2 & 0.162 & 1.98 & 6.26 & $3.45 \pm 0.15$ & 43 & 35 & 22 & $4.44 \pm 20$ \\
\hline D2083 & 20.7 & 2.1 & 0.215 & 2.08 & 6.58 & $4.13 \pm 0.20$ & 45 & 38 & 17 & $0.93 \pm 0.10$ \\
\hline D2084 & 15.4 & 2.5 & 0.225 & 2.69 & 8.51 & $4.50 \pm 0.26$ & 48 & 38 & 14 & $1.09 \pm 0.10$ \\
\hline D2085 & 17.6 & 1.4 & 0.181 & 2.39 & 7.55 & $3.92 \pm 0.16$ & 48 & 34 & 18 & $1.00 \pm 0.09$ \\
\hline D2086 & 10.7 & 0.9 & 0.080 & 2.64 & 8.35 & $2.86 \pm 0.13$ & 34 & 41 & 25 & $0.6 \pm 0.05$ \\
\hline D2088 & 16.9 & 0.8 & 0.080 & 1.93 & 6.10 & $2.45 \pm 0.11$ & 32 & 42 & 26 & $0.65 \pm 0.05$ \\
\hline D2090 & 11.5 & 1.5 & 0.110 & 1.62 & 5.14 & $3.23 \pm 0.14$ & 33 & 44 & 23 & $0.84 \pm 0.08$ \\
\hline D2094 soil & & 1.1 & & 1.57 & 4.98 & & & & & \\
\hline D2095 clay & & 0.8 & & 1.63 & 5.14 & & & & & \\
\hline
\end{tabular}

The $a$ value is the relative efficiency of alpha vs. beta radiation inducing TL 
Table 3 Samples listed based on the absolute chronology obtained by thermoluminescence dating

\begin{tabular}{llrlrll}
\hline Sample & Shape & Type & Proposed chronology & \multicolumn{1}{l}{ TL } & & Chronology \\
\hline D2074 & Bottle & 63 & Second half 1st cen. A.D. & $45 \pm 140$ d.C. & Roman \\
D2076 & Jug & 46 & Second half 1st cen. A.D. & $55 \pm 130$ d.C. & \\
D2077 & Bottle & 60 & Second half 1st cen. A.D. & $120 \pm 125$ d.C. & \\
D2067 & Cup & 84 & Islamic & $180 \pm 120$ d.C. & \\
D2078 & Stewpot & 148 & Roman period & $720 \pm 90$ d.C. & Islamic \\
D2069 & Jug & 38 & 6th-9th cen. A.D. & $770 \pm 85$ d.C. & \\
D2071 & Jug & 41 & 10th-11th cen. A.D. & $1,010 \pm 80$ d.C. & \\
D2072 & Jug & 52 & 10th-11th cen. A.D. & $995 \pm 85$ d.C. & \\
D2083 & Cup & 80 & - & $1,780 \pm 25$ d.C. & \\
D2084 & Basin & 17 & - & $1,805 \pm 20$ d.C. & \\
D2085 & Cup & 77 & - & $1,750 \pm 30$ d.C. & \\
D2086 & Cup & 129 & - & $1,795 \pm 30$ & d.C. & \\
D2088 & Cup & 81 & - & $1,740 \pm 35$ d.C. & \\
D2090 & Pan & 138 & - & $1,745 \pm 30$ & d.C. & \\
\hline
\end{tabular}

reports the dating results obtained on 14 of the 21 samples submitted to dating. Seven samples could not be dated due to the absence of natural TL emission and poor dosimetric characteristics.

The attempt to circumvent these problems using the predose technique also failed. This technique is an alternative way of determining the equivalent dose. It is based on the changes in sensitivity of the low temperature peak of quartz $\left(110^{\circ} \mathrm{C}\right.$ at a heating rate $\left.15^{\circ} \mathrm{C} / \mathrm{s}\right)$ after irradiation and heating cycles, which is proportional to the archaeological dose. Whilst a few samples did not show any sensitisation, in others, the observed changes in sensitivity were not linear. This could suggest that in the grain size range 2$8 \mu \mathrm{m}$, quartz was not the main mineralogical phase present in these samples.

TL dating results essentially confirmed the proposed archaeological chronology, except in two cases. It is worth observing that the six samples of unknown period resulted coeval and dated with high precision $1770+25$ A.D.

X-ray fluorescence

Results are reported in Table 4. Samples show variable $\mathrm{CaO}$ contents: five specimens contain less than $2 \mathrm{wt} \%$, seven contain 4.7-9.44 wt.\% and seven contain 10.2-15.9 wt.\%. The ample variations in $\mathrm{SiO}_{2}\left(49.5-71.5\right.$ wt.\%), $\mathrm{Al}_{2} \mathrm{O}_{3}$ (11.2-19.1 wt.\%), $\mathrm{Fe}_{2} \mathrm{O}_{3}$ (4-10 wt.\%), $\mathrm{MgO}$ (0.5-3.6 wt.\%), $\mathrm{Na}_{2} \mathrm{O}\left(0.3-1.7\right.$ wt.\%) and $\mathrm{K}_{2} \mathrm{O}(1.1-3.1$ wt.\%) contents, and in both minor and trace elements, are such to describe a heterogeneous context. Based on major, minor and trace element contents, compositional groupings can be weakly established between (a) D2074, 2078, D2067 and D2076, (b) D2071, D2072 and D2088, (c) D2089, D2085, D2079 and D2081, (d) D2083, (e) D2075, D2087 and D2077, (f) D2069 and D2084, (g) D2086, (h) D2090. Groups a, b and $f$ are rather homogeneous, groups $\mathrm{c}$ and e show a wider heterogeneity, groups $\mathrm{d}, \mathrm{g}$ and $\mathrm{h}$ include one sample each. D2090 greatly differs from all other samples, especially based on $\mathrm{Fe}_{2} \mathrm{O}_{3}, \mathrm{~V}, \mathrm{Cr}, \mathrm{Co}, \mathrm{Y}, \mathrm{La}$ and $\mathrm{Ce}$ contents.

\section{Optical microscopy and scanning electron microscopy}

Textural observations performed by OM and SEM suggest to distinguish ceramic bodies into very fine (D2069, D2082), fine (D2067, D2077, D2083, D2084), medium (D2071-D2072, D2074, D2076), coarse (D2078) and very coarse (D2085, D2090). D2087 and D2090 further show an oriented matrix.

Matrix prevails on skeleton in D2069 and D2082 (90\% matrix) and in D2071 and D2074 (70\% matrix). Mean grain size is of $\sim 100 \mu \mathrm{m}$ in the skeleton of the first couple, whilst it increases in the second couple up to $\sim 200 \mu \mathrm{m}$. Approximately the same percentage of matrix and skeleton can be observed in D2077, D2083 and D2084. Mean grain size is of $\sim 60$ and $\sim 150 \mu \mathrm{m}$ in the skeleton of D2083 and of D2077 and 2084, respectively. Skeleton prevails on matrix in D2078, D2085 and D2090, being mainly constituted by quartz (mean dimensions, 200-250 $\mu \mathrm{m}$ ) in D2078, lithic fragments (mean dimensions, $800 \mu \mathrm{m}$ ) in D2085, quartz (mean dimensions, $250 \mu \mathrm{m}$ ) and lithic fragments (mean dimensions, $600 \mu \mathrm{m}$ ) in D2090.

Quartz represents the main mineralogical phase in all samples, whilst the assemblages varies considerably per sample. K-feldspars are ubiquitous, always prevalent on plagioclases. The latter vary considerably in composition: albite in D2071, D2074, D2076-2078, D2087 and D2090, from albite to andesine in D2083, from albite to labradorite D2069, D2072, D2085. Calcite is often abundant as secondary phase, whilst primary calcite has been rarely observed. Phyllosilicates are ubiquitous, mainly represented 





by muscovite, particularly abundant in D2090, and biotite, sometimes chloritised (D2069, D2083, 2087) or particularly rich in Al (D2090). Abundant in D2076 and D2084 and frequent in all other samples, chlorites shows a Mg- and Ferich composition. Pyroxenes have been observed in D2071, D2072, D2074, D2078 and D2085, mainly represented by augite; sporadic crystals show intermediate composition between enstatite and pigeonite (D2069). Garnets show intermediate composition between almandine and pyrope in D2074 and D2078. Amphiboles are sporadically observed in D2076, D2074 and D2078, whilst they are abundant in D2069 and D2090. In the former sample, the amphiboles show variable compositions between anthophyllite and $\mathrm{Mg}$-hornblende; in the latter, abundant hornblende is present in granitoid inclusions. Epidotes are sporadically observed but frequent in D2071, D2074, D2076 and D2078. Fe and Ti oxides are ubiquitous, as well as titanite, apatite and zircon. D2085 further shows a chromiferous spinel. Lithic fragments are generally infrequent, show small dimensions and are mainly represented by argillaceous rock fragments, limestones and sandstones; on the contrary, D2090 shows abundant granitoid inclusions up to $1 \mathrm{~mm}$, made of quartz, K-feldspar, biotite, hornblende and minor plagioclase. Microphauna is generally very rare, with the exception of D2087, characterised by abundant microfossil content.

\section{Discussion}

Proposed chronologies have been denied twice. Thermoluminescence demonstrated that D2067 dates back to the second century A.D., whilst archaeological typology suggested a comparison with the production from the Islamic archaeological site of Badis. Vice versa, the stewpot D2078, framed into the Roman period, resulted to be an eighth century A.D. production. The unknown productions can be now dated within the eighteenth century A.D.

As far as characterisation, present data must be discussed in relation to Thamusida reference groups for bricks and amphoras (Gliozzo and Camporeale 2009; Gliozzo and Cerri 2009). Bulk chemical composition suggests indicating samples D2074, D2078, D2067 and D2076 as local productions. Mineralogical-petrograhical observations seem to further confirm this hypothesis. Quartz prevalent on all remaining phases, K-feldspars prevalent on plagioclases (from albite to labradorite), rare primary calcite, abundant secondary calcite, frequent phyllosilicates (muscovite, biotite and $\mathrm{Mg}$ - and Fe-rich chlorites), sporadic to frequent amphiboles (antophyllite, gedrite/Fe-gedrite, edenite/Fe-edenite, pargasite/Fe-pargasite), rare to sporadic garnets (with intermediate compositions between pyrope and almandine), rare pyroxenes (augite), abundant epidote,
$\mathrm{Fe}$ and $\mathrm{Ti}$ oxides and other accessory minerals such as titanite, apatite and zircons are the principal characteristics of Thamusida local ceramic productions. The same assemblages have been observed in those four samples showing a bulk chemical correspondence with Thamusida local production.

Lithic fragments content is decisive for sample D2090. The granitoid inclusions definitely exclude the territory of Thamusida as an option, whilst they can maybe address the Hercynian granitoids of the Central Palaeozoic Massif of Morocco (see, e.g. Mahmood and Bennani 1984). Microphauna content further help in distinguishing D2087 both from Thamusida local production and all other samples here analysed.

From a technological standpoint, there is no apparent relation between composition and function. For instance, calcareous clays have been mainly used for tableware, but also for D2078 which is a stewpot. The supply of raw materials seems to reflect the available outcrops surrounding production plant more than a technological choice. Pan D2090 represents an exception again, showing well-suited raw materials, with little plasticity and consisting of prevalently sandy matrices rich in quartz, iron oxides and lithic inclusions and poor in Ca-bearing minerals.

\section{Conclusions}

The general purpose of this study has been to improve knowledge on common ware over different time periods. Notwithstanding the limited number of samples, it is clear that there are problems in dating common ware from Morocco, mainly due to the scarcity of available archaeological typologies. Hence, the data collected will be used to guide the typological study, bearing in mind that numerous shapes of common ware have been widely reproduced for centuries. The information arising from this research are definitely useful for the study of the site of Thamusida, but they are also of great relevance for all researchers involved in archaeological and archaeometrical research in Morocco. The identification of an eighteenth century ceramic production is of outstanding importance, as it characterises a completely unknown production and opens new opportunities of study.

Regarding the geography of production, four samples of both Roman and Islamic periods have been recognised as local productions of Thamusida. The majority of the remaining samples could be ascribed to a nearby territory, as mineralogical and petrographical investigations do not show significant differences from products of Thamusida. The provenance of pans D2087 and D2090 remain obscure; however, the granitoid inclusions in D2090 could indicate the areas of Ment, Zaer or Oulmes. 
Acknowledgements Authors gratefully acknowledge Prof. Eliane Lenoir for many fruitful discussions.

\section{References}

Aitken MJ (1985) Thermoluminescence dating. Academic, London Aranegui Gascó C (2001) Lixus, Saguntum, Papeles del laboratorio de arqueología de Valencia, extra-4, Valencia.

Aranegui Gascó C (2005) Lixus-2 Ladera Sur, Saguntum, Papeles del laboratorio de arqueología de Valencia, extra-6, Valencia.

Benco NL (1987) The early medieval pottery industry at al-Basra, Morocco. BAR, Int Ser 341:212

Benco NL (2002) Archeological investigation at al-Basra, Morocco. Bull Archéol Maroc 19:293-340

Bernal Casasola D (1994) Marcas sobre materiales de construcción de época romana en Ceuta y la problemática de la necrópolis de las Puertas del Campo. Transfretana 6:61-80

Boube J. (1999). Les nécropoles de Sala, Paris.

Camporeale S (2008) I bolli sui laterizi. In: Akerraz A, Papi E (eds) Sidi Ali Ben Ahmed-Thamusida 1. Les contextes-I contesti. Quasar, Roma, pp 201-213

Cerri L (2008) La prospezione magnetica: l'abitato antico. In: Akerraz A, Papi E (eds) Sidi Ali Ben Ahmed-Thamusida 1. Les contextes-I contesti. Quasar, Roma, pp 33-52

D'Aco D (2005) Il paesaggio economico di un vicus romano: Thamusida (Marocco). Importazioni, produzioni locali e consumi attraverso lo studio delle ceramiche. Degree thesis

Decret F, Fantar M (1981) L'Afrique du Nord dans l'Antiquité. Histoire et civilisation (Dés origines au Ve siècle), Paris
Galli A, Martini M, Montanari C, Panzeri L, Sibilia E (2006) TL of fine-grain samples from quartz-rich archaeological ceramics: dosimetry using the 110 and $210^{\circ} \mathrm{C}$ TL peaks. Radiat Meas 41:1009-1014

Gliozzo E, Camporeale S (2009) I laterizi. In: Gliozzo E, Memmi Turbanti I, Papi E (eds) Sidi Ali Ben Ahmed-Thamusida 2, Archeometrie-Archeometria. Quasar, Roma, pp 149-184

Gliozzo E, Cerri L (2009) Le anfore. In: Gliozzo E, Memmi Turbanti I, Papi E (eds) Sidi Ali Ben Ahmed-Thamusida 2. ArcheometrieArcheometria. Quasar, Roma, pp 185-216

Lugan B (2000) History of Morocco. Edition Perrin et Critérion, Paris

Mahmood A, Bennani A (1984) S-type characteristics of the Hercynian granitoids of the Central Palaeozoic Massif, Morocco. Geol Mag 121:301-311

Redman ChL (1979-1980) La céramique du moyen-age tardif à qsar es-seghir. Bulletin d'Archéologie Marocaine 12:291-305

Redman ChL (1983-1984) Survey and test excavation of six medieval Islamic sites in Northern Morocco. Bull Archéol Maroc 15:311350

Redman ChL, Anzalone RD, Rubertone PE (1977-1978) Qsar esSeghir, Three seasons of excavation. Bull Archéol Maroc 11:291-305

Redman ChL, Boone JL, Myers JE (1979-1980) Fourth season of excavations at Qsar Es-Seghir. Bull Archéol Maroc 12:263-284

Sigman MC (1977) The roman and the indigenous tribes of Mauretania Tingitana. Historia 26:415-439

Villaverde Vega N (2001) Tingitana en la antigüedad tardía (siglos IIIVII): Autoctonía y romanidad en el extremo Occidente Mediterráneo, Madrid

Zimmermann DW (1971) Thermoluminescent dating using fine grains from pottery. Archaeometry 13:29-52 